\title{
Engineering Novel and Improved Biocatalysts by Cell Surface Display
}

\author{
Mason R. Smith, ${ }^{\dagger}$ Eshita Khera, ${ }^{\ddagger}$ and Fei Wen ${ }^{*} \dagger$ \\ ${ }^{\dagger}$ Department of Chemical Engineering, University of Michigan, Ann Arbor, Michigan 48109, United States \\ ${ }^{\ddagger}$ Department of Biomedical Engineering, University of Michigan, Ann Arbor, Michigan 48109, United States
}

ABSTRACT: Biocatalysts, especially enzymes, have the ability to catalyze reactions with high product selectivity, utilize a broad range of substrates, and maintain activity at low temperature and pressure. Therefore, they represent a renewable, environmentally friendly alternative to conventional catalysts. Most current industrial-scale chemical production processes using biocatalysts employ soluble enzymes or whole cells expressing intracellular enzymes. Cell surface display systems differ by presenting heterologous enzymes extracellularly, overcoming some of the limitations associated with enzyme purification and substrate transport. Additionally, coupled with directed evolution, cell surface display is a powerful platform for engineering enzymes with enhanced properties. In this review, we will introduce the molecular and cellular principles of cell surface display and discuss how it has been applied to engineer enzymes with improved properties as well as to develop surface-engineered microbes as whole-cell biocatalysts.

\section{INTRODUCTION TO BIOCATALYSIS}

Biocatalysis is the subfield of reaction engineering concerned with the application of enzymes for chemical production. ${ }^{1,2}$ Similar to conventional catalysts, enzymes are not consumed by a chemical reaction; instead, both accelerate the reaction rate by providing an alternative reaction path characterized by a lower activation energy. While the fundamental thermodynamics governing the action of enzymes and conventional catalysts are identical, several properties associated with enzymes are considered to be advantageous for industrial processes, ${ }^{3}$ such as higher catalytic efficiency, ${ }^{2}$ product selectivity, ${ }^{3-6}$ ability to catalyze chemical reactions under mild conditions, ${ }^{7}$ and biodegradability. ${ }^{3,4,6}$ As such, the global market for industrial biocatalysis is expected to grow to 5.5 billion USD through 2015 with increasing applications in the production of detergents, alcohols, textiles, and pharmaceuticals. ${ }^{8}$

Current industrial biocatalysis is based largely on the use of cell-free or intracellular enzyme systems (Figure 1). Cell-free systems are typically used for cofactor-independent reactions ${ }^{1}$ and require purification of the enzymes from high-density cell cultures using liquid chromatography or liquid-liquid extraction to minimize downstream separation difficulties and competing reactions from contaminant enzymes in the cell lysate. ${ }^{9}$ Cell-free enzymes have direct access to substrate in solution and, as a result, often exhibit reaction-rate limited kinetics. However, these systems lack the important ability to piggyback on the natural metabolic network of the cell, limiting their application to simple reactions. In contrast to cell-free systems, intracellular enzyme systems first require internalization of the substrate via active or passive transport mechanisms. Because the rate of substrate internalization is almost always lower than the rate of reaction, the kinetics governing intracellular enzyme biocatalysts are masstransport limited and typically 10 - to 100 -fold slower ${ }^{10,11}$ than cell-free enzymes. Despite slower kinetics, intracellular enzyme expression systems are commonly used in chemical synthesis. ${ }^{1}$ This is primarily due to their ability to utilize cofactor-dependent enzymes, as living cells can couple metabolic reactions to regenerate oxidized and reduced forms of cofactors. Additionally, these systems are less expensive to prepare than purified cell-free enzymes, and the tightly regulated intracellular environment protects enzymes from toxic and potentially inhibitory reaction conditions. $^{12,13}$

Despite demonstrated success, many industries have been reluctant to adopt enzyme biocatalysts in large-scale production processes. The most commonly cited drawbacks associated with enzyme biocatalysts have included process condition limitations, susceptibility to substrate/product inhibition, decreased activity in non-aqueous environment, low production capacity, and the lack of naturally occurring enzymes capable of mediating desired chemical transformations. ${ }^{14}$ Addressing some of these shortcomings, the breakthroughs in our understanding of cellular biology and protein engineering have helped to rapidly advance the field of biocatalysis. This evolution has been described by Bornscheuer et al. as the "three waves of biocatalysis"15 (Figure 2 ). In particular, the third wave, characterized by the implementation of directed evolution strategies, pioneered by Frances Arnold and Willem Stemmer around the turn of the 21st century, ${ }^{16}$ has been the most crucial of all. In addition to enhancing existing enzymatic properties, directed evolution has empowered researchers to develop enzymes with novel capabilities and utilize heterologous reaction pathways. ${ }^{15}$ The maturation of cell surface display technology at the turn of the second and third waves enabled researchers to harness its natural ability to link genotype and phenotype as a powerful libraryscreening tool for protein engineering, especially via directed evolution. Moreover, novel whole-cell biocatalysts have been engineered using surface-displayed enzymes. Enzyme cell surface display allows whole cells to readily access soluble substrate while retaining the metabolic potential of intracellular enzyme systems

Special Issue: Scott Fogler Festschrift

Received: October 14, 2014

Revised: January 8, 2015

Accepted: January 20, 2015

Published: January 20, 2015 
Biocatalyst Complexity

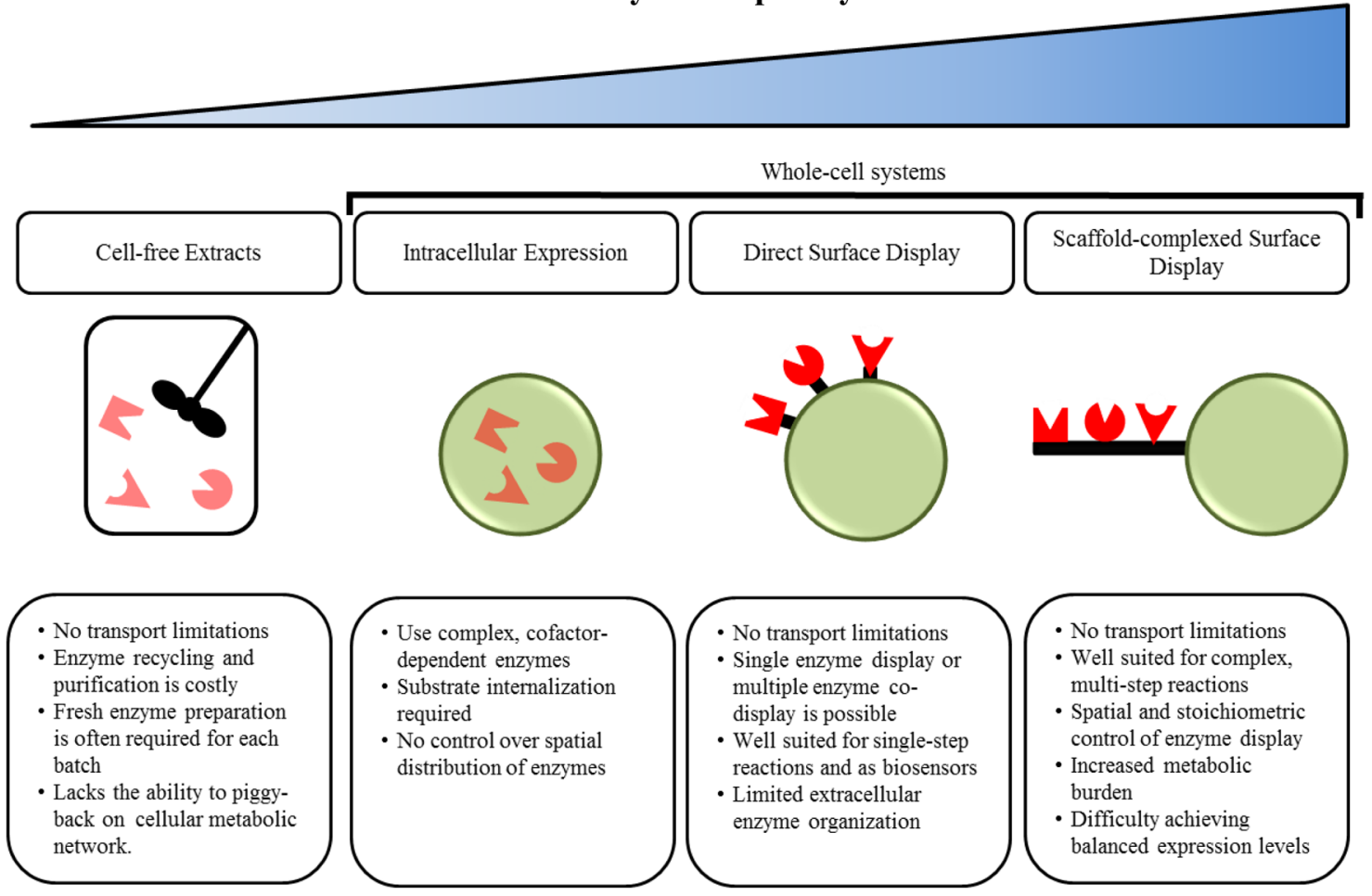

Figure 1. Comparison of biocatalytic systems ranging in complexity. The pros and cons of each system are summarized.

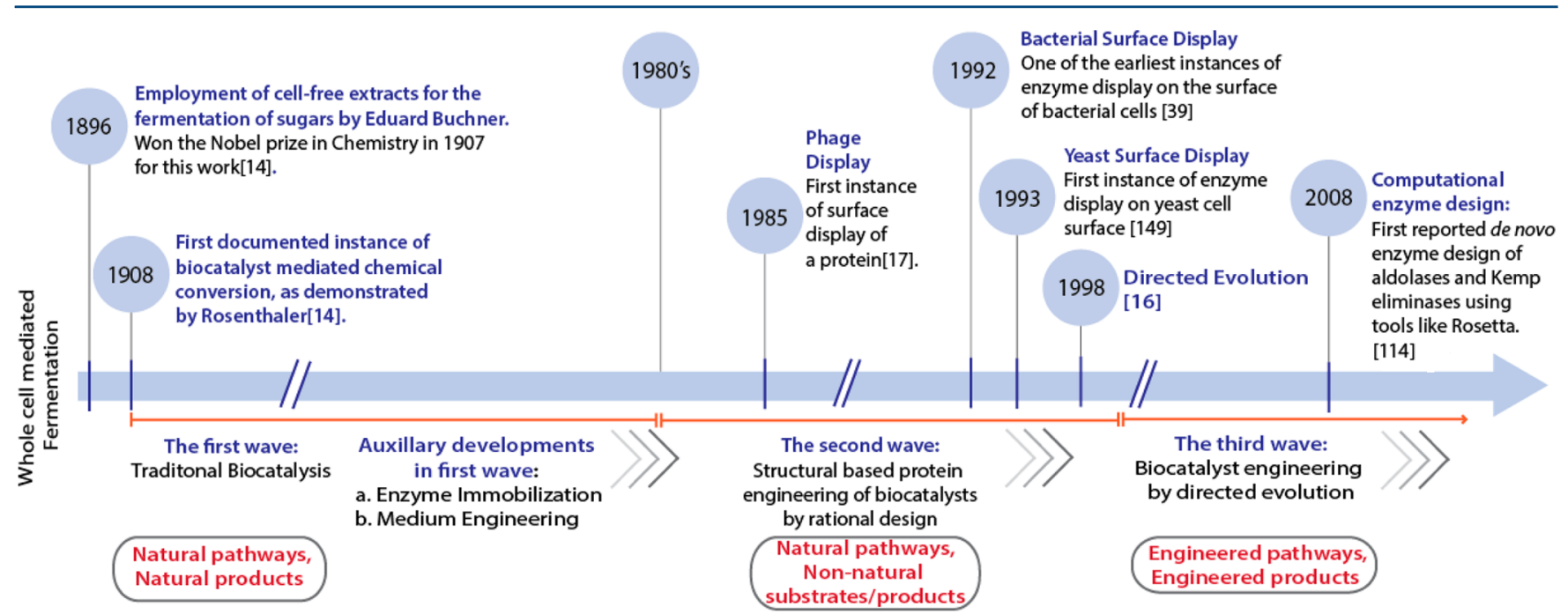

Figure 2. Timeline depicting the synergistic overlap of biocatalysis evolution and maturation of surface display ${ }^{39,149}$ as a tool for biocatalyst engineering. The evolution of biocatalysis, detailed in three waves, ${ }^{15}$ transitions from the utilization of natural metabolic pathways for the production of natural products (first wave) to the exploitation of natural pathways and enzymes for the generation of non-natural products (second wave) to engineering nonnatural pathways for novel product generation (third wave).

(e.g., extracellular degradation of cellulose and internalization of the major product, glucose, to produce ethanol). In this review, we will compare commonly used surface display systems and discuss how they, coupled with breakthroughs in the field of protein engineering, have generated new excitement about expanding the use of engineered enzyme biocatalysts in industry.

\section{MOLECULAR AND CELLULAR PRINCIPLES OF CELL SURFACE DISPLAY}

Cell surface display systems have explored a variety of host organisms with a varying degree of complexity ranging from viral capsids $^{17,18}$ to bacterial spores ${ }^{19}$ to prokaryotes $^{20}$ to eukaryotes. ${ }^{21}$ Despite differences in the host organisms, surface display systems often have three core features in common: (a) a signal peptide to direct the protein of interest toward the secretory pathway, (b) an endogenous surface protein amenable to recombination (i.e., insertion, deletion, and fusion) to enable stable surface anchorage of the target protein, and (c) an epitope tag to facilitate the detection of successful surface display. Currently, no one-size-fits-all surface display platform exists, and the most suitable host system depends on several factors, including the complexity of the recombinant enzyme being 
Table 1. Comparison of Cell Surface Display Systems with Significance in Biocatalysis

\begin{tabular}{|c|c|c|c|}
\hline & phage & prokaryote & eukaryote \\
\hline $\begin{array}{l}\text { Commonly used } \\
\text { host organisms }\end{array}$ & $\begin{array}{l}\text { Filamentous phages fd, M13; Enterobacteria phages } \\
\text { T4, T7, lambda, phagemid }\end{array}$ & E. coli, B. subtilis, L. bacillus, S. carnosus & S. cerevisiae, P. pastoris \\
\hline $\begin{array}{l}\text { Typical library } \\
\text { size }\end{array}$ & $1 \times 10^{10}$ to $1 \times 10^{12}$ & $1 \times 10^{8}$ to $1 \times 10^{10}$ & $1 \times 10^{6}$ to $1 \times 10^{7}$ \\
\hline $\begin{array}{l}\text { Post- } \\
\text { translational } \\
\text { machinery }\end{array}$ & Capable of simple post- translational modifications & $\begin{array}{l}\text { Capable of moderate post-translational } \\
\text { modifications }\end{array}$ & $\begin{array}{l}\text { Capable of sophisticated post- } \\
\text { translational modifications }\end{array}$ \\
\hline $\begin{array}{l}\text { Surface } \\
\text { anchorage }\end{array}$ & Capsid proteins & $\begin{array}{l}\text { Lpp-OmpA, autotransporter proteins, ice } \\
\text { nucleation proteins }\end{array}$ & $\begin{array}{l}\text { Agglutination proteins, flocculation } \\
\text { proteins }\end{array}$ \\
\hline $\begin{array}{l}\text { Main } \\
\text { applications }\end{array}$ & $\begin{array}{l}\text { Peptide affinity maturation, peptide-DNA } \\
\text { interactions, phage assisted continuous evolution } \\
\text { (PACE) }\end{array}$ & $\begin{array}{l}\text { Directed evolution for modification of } \\
\text { nonmammalian proteins, biocatalysis, } \\
\text { genotype-phenotype studies }\end{array}$ & $\begin{array}{l}\text { Directed evolution of mammalian } \\
\text { proteins, biocatalysis, genotype- } \\
\text { phenotype studies }\end{array}$ \\
\hline
\end{tabular}

displayed and its intended application (Table 1). In this section, we will introduce and compare some of the more widely used surface display systems pertinent to biocatalysis.

2.1. Phage Display Systems. Bacteriophages (phages) comprise a diverse group of viruses that infect prokaryotic organisms. One of the first successful demonstrations of the surface display of peptides was accomplished using a phage display system. ${ }^{17}$ Phage display has been, and continues to be, used for many diverse applications, including antibody affinity maturation, ${ }^{22-24}$ selection of molecular imaging probes, ${ }^{25,26}$ antigen identification for vaccine development, ${ }^{27,28}$ and the discovery of novel enzyme substrates and inhibitors. ${ }^{29-31}$ However, phage display is inherently limited by the posttranslational machinery of its bacterial host as well as the size of the target protein. As a result, phage display systems lack the ability to present diverse libraries of large, full-length heterologous enzymes. Nevertheless, they still play an important role in improving the properties of enzyme biocatalysts. For example, phage display has been used to select improved enzyme subunits, ${ }^{32}$ to study substrate binding and enzyme inhibition, ${ }^{33}$ and to assess the interactions between small molecules and enzymes. $^{33}$

2.2. Prokaryotic Display Systems. In order to account for some of the limitations associated with phage display, a number of prokaryotic cell-surface display systems have been developed. The greatest advantage of prokaryotic display over phage display is the ability to screen and sort cells using fluorescence activated cell sorting (FACS). ${ }^{34}$ Prokaryotic systems are also capable of presenting larger, more complex polypeptides than phage display systems. ${ }^{35}$ Furthermore, most bacteria express a high number of native anchor proteins. This allows for high-level surface display of foreign enzymes without exhibiting avidity effects associated with the use of some abundant phage capsid proteins. ${ }^{36}$ Escherichia coli has emerged as the most widely used host primarily due to its well-established genetic toolbox and its ability to achieve high-density surface display of full-length recombinant proteins. A detailed review of diverse prokaryotic surface display systems can be found elsewhere. ${ }^{37,38}$ Here, we will provide an overview that will serve to emphasize the significance of prokaryotic cell surface display in engineering novel and improved biocatalysts.

E. coli cell surface display is accomplished by fusing a target protein (the passenger) to a native surface protein (the carrier) anchored in the outer membrane. The carrier protein mediates the transport of the passenger through the E. coli inner membrane and periplasm for stable anchoring in the outer membrane. The properties of the carrier protein dictate the orientation (i.e., $\mathrm{N}$ - or C-terminal fusion) and the size limit of the target gene. For example, complications in outer membrane localization using outer membrane protein $\mathrm{A}(\mathrm{OmpA})$ as the carrier were observed when attempting to surface display large target proteins. ${ }^{39}$ This issue was addressed by fusing the signal and the first nine amino acids of a lipoprotein (Lpp) to the Nterminal region of OmpA and has been used to display many functionally diverse heterologous enzymes. ${ }^{40,41}$

While Lpp-OmpA is among the most widely used carrier proteins for prokaryotic surface display, recent efforts have focused on two carrier proteins: autotransporter proteins ${ }^{42}$ and ice nucleation proteins (INPs). ${ }^{43}$ Autotransporter protein display (autodisplay) has two significant advantages over traditional prokaryotic surface display systems including LppOmpA. First, autotransporter proteins are relatively simple, modular proteins. ${ }^{44}$ This modular structure allows the native passenger protein (typically, a virulence factor) to be readily exchanged to display the desired heterologous enzyme on the bacterial cell surface. ${ }^{45}$ The second advantage of the autodisplay systems lies in the mobility of the $\beta$-barrel anchor, ${ }^{45}$ which allows the autodisplayed proteins to form multimers by associating in the membrane after expression. This has been demonstrated for several dimeric enzymes ${ }^{46,47}$ and could be adapted to display functional heterodimers and multimers. ${ }^{48}$ Autodisplay systems are also capable of displaying $>180000$ copies of autotransporter-fused enzyme per cell, rivaling the expression of endogenous E. coli surface proteins (100 000-200 000 copies). ${ }^{44}$ Similar to autodisplay, INP-based display systems are capable of achieving higher surface display levels than Lpp-OmpA. ${ }^{49}$ In addition, INPs contain a highly degenerate internal region that has been used as a scalable linker to display heterologous enzymes at varying distances from the cell surface. ${ }^{50}$ This has allowed large fusion proteins to be surface displayed without prokaryotic cell-surface interference.

While greatly expanding the potential of cell surface display beyond phage display systems, prokaryotic systems also have their own limitations. Prokaryotes are capable of performing only relatively simple post-translational modifications and are known to exhibit expression bias against more complex mammalian proteins. $^{21}$ Additionally, most prokaryotes lack the innate machinery to produce and tolerate high levels of toxic metabolites, such as ethanol. ${ }^{51}$

2.3. Eukaryotic Display Systems. To address some of the limitations of prokaryotic display, several eukaryotic surface display systems have been explored, ranging from yeast to insect $^{52}$ to mammalian cell display. ${ }^{53}$ These eukaryotic display systems, particularly yeast display, offer several distinct advantages, including the ability to fold, process, and present complex heterologous proteins, ${ }^{21}$ the availability of an established genetic toolbox, and the ability to tolerate harsh conditions by exhibiting cross-protection ${ }^{54-56}$ against environ- 
mental stresses. A detailed review of yeast surface display mechanisms can be found elsewhere. ${ }^{57,58}$ Here, we will introduce some of the more common yeast surface display systems with demonstrated relevance in biocatalysis.

The mating-type-specific agglutination proteins, a- and $\alpha$ agglutinin, have been among the most widely used anchor proteins for yeast surface display. ${ }^{57}$ The a-agglutinin protein consists of two units linked by a disulfide bridge: the Aga 1 anchor and an Aga 2 carrier. This disulfide bridge is a prominent feature of a-agglutinin-based display, as it provides a natural spacer between the target protein and the cell surface. In contrast, the $\alpha$ agglutinin protein consists of a single anchor unit, Ag $\alpha 1$. Another important difference between the two agglutinin-based surface display systems is the orientation of the target protein. aAgglutinin is more commonly used for enzymes with a Cterminal functional domain, whereas $\alpha$-agglutinin is more commonly used for those with a functional domain near the N-terminus. ${ }^{58,59}$ The agglutinin-based display systems have been adapted to display a diverse array of peptides, enzymes, and structural proteins on the yeast cell surface for a plethora of applications ranging from antibody affinity maturation to biofuel production. ${ }^{58-64}$ Another group of anchor proteins used for yeast surface display are flocculation proteins. The yeast flocculation protein, Flo1, ${ }^{65}$ has been widely used to display functional lipases on the surface of both Saccharomyces cerevisiae $^{66}$ and Pichia pastoris. ${ }^{67,68}$ Additionally, it has been shown in some cases that the fusion of the target enzyme to the flocculation protein does not abolish its native function. ${ }^{69,70}$ The resulting flocculation phenotype is often desirable because it can serve as an indicator of nutrient depletion in media, and the yeast flocs can be easily separated from a liquid suspension. ${ }^{71,72}$

While yeast surface display has helped to advance the field of protein engineering, it is not without its limitations. First, yeast cell growth is significantly slower than that of most bacteria, which may hamper the economic viability of processes utilizing yeast-based whole-cell biocatalysts. Another commonly cited drawback associated with yeast surface display is its low transformation efficiency (Table 1), which limits the enzyme mutant library size of directed-evolution-based engineering strategies in yeast, as discussed below.

\section{CELL SURFACE DISPLAY FOR ENGINEERING INDUSTRIAL BIOCATALYSTS}

While nature has provided a plethora of functionally diverse enzymes, most have evolved to operate within a narrow range of physiological conditions. As a result, many wild-type enzymes cannot function in the harsh environments associated with industrial processes. To address this issue, researchers have used directed evolution and cell surface display to engineer and select mutant enzymes better suited to handle industrial processing (Section 3.1). In addition to serving as a powerful tool for protein engineering, cell surface display of modified or wild-type enzymes can be used to create novel whole-cell biocatalysts for use in chemical processes ranging from biofuel production and petroleum refining to environmental pollutant detection. ${ }^{58,73-76}$ Two surface-display strategies are currently being explored for this purpose: (a) direct surface display of multiple enzymes in a noncomplexed form (Section 3.2) and (b) complexed display of enzymes organized on surface-displayed protein scaffolds (Section 3.3) as depicted in Figure 1.

3.1. Direct Cell Surface Display of Single Enzymes. The simplest form of cell surface display employs the direct genetic linkage of the target enzyme to a transmembrane anchorage protein of the cell. Coupling this direct cell surface display of single enzymes with directed evolution has emerged as a powerful approach for engineering and high-throughput screening of biocatalysts with improved properties. A typical application of this approach consists of five steps (Figure 3):

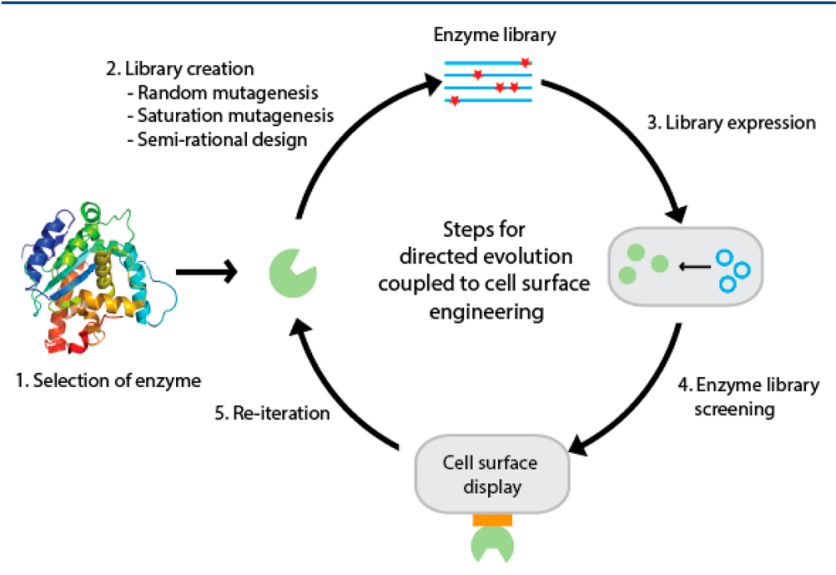

Properties engineered

$\begin{array}{cc}\text { Activity } & \begin{array}{c}\text { Substrate } \\ \text { Specificity }\end{array} \\ \text { Selectivity } & \text { Stability }\end{array}$

Figure 3. Overview of the application of cell surface display as a highthroughput screening tool for biocatalyst engineering via directed evolution.

(i) selection of an enzyme as the engineering target, (ii) generation of a library of enzyme mutants by random or semirational mutagenesis, (iii) cellular expression of the mutant library, (iv) cell surface display of the expressed enzymes for selection of mutants exhibiting enhanced properties, and ( $\mathrm{v}$ ) reiteration of these four steps to enrich the selected mutant populations with improved properties. ${ }^{76-78}$ In this section, we will describe how cell surface display of single enzymes has been used in conjunction with directed evolution to engineer novel and improved biocatalysts. Specific properties with importance in industrial processes include, but are not limited to, thermostability, tolerance to organic solvents, activity, substrate specificity, and enantioselectivity of reaction products. ${ }^{79-81}$ Some of the recent applications of the five-step engineering approach have been summarized in Table 2 . In the discussion below, we will focus on studies that have introduced new aspects to the five-step engineering approach.

3.1.1. Enzyme Stability and Solvent Tolerance. Many industrial processes operate at temperatures, $\mathrm{pH}$ ranges, and chemical/solvent conditions not optimal for maintaining the stability of wild-type enzymes. Therefore, a considerable effort has been made to engineer more robust enzyme biocatalysts with improved stability under non-ideal conditions. One of the most industrially relevant properties of biocatalysts is their thermostability. To date, only a few studies have reported the use of cell surface display to improve the thermostability of enzymes (Table 2). This may be due to the intrinsic thermal instability of unadapted living cells and protective mechanisms triggered (upregulation of heat shock proteins, suspension of protein transcription and translation, etc.) under extreme temperature conditions ${ }^{82}$ that can detrimentally affect the expression level of the enzyme library. Studies have evaluated the thermostability profile of mutated enzymes using cell surface display up to moderately high temperatures $\left(70^{\circ} \mathrm{C}\right)$ and showed greater than 
Table 2. Recent Progress in Biocatalyst Engineering Based on the Use of Cell Surface Engineering as a Tool for Directed Enzyme Evolution

\begin{tabular}{|c|c|c|c|c|c|}
\hline & enzyme & enzyme characteristics & $\begin{array}{l}\text { anchor } \\
\text { protein }\end{array}$ & host organism & property engineered \\
\hline \multirow[t]{2}{*}{ Oxidoreductase } & $\begin{array}{l}\text { Horseradish } \\
\text { peroxidase }\end{array}$ & $\begin{array}{l}44 \mathrm{kDa} \text {; glycoprotein metalloenzyme, heme group, } 2 \text { calcium } \\
\text { atoms; single chain polypeptide, } 4 \text { disulfide bridges }\end{array}$ & Aga2 & S. cerevisiae & $\begin{array}{l}\text { Activity } \\
\text { Enatioselecivity }^{110}\end{array}$ \\
\hline & $\begin{array}{l}\text { Glucose } \\
\text { dehydrogenase }\end{array}$ & $\begin{array}{l}112 \mathrm{kDa} \text {; short chain dehydrogenase reducatase enzyme; } \\
\text { homotetramer }\end{array}$ & INP & E. coli & $\begin{array}{l}\text { Substrate specificity } \\
\text { and stability }\end{array}$ \\
\hline Transferase & $\begin{array}{l}\text { Sfp phosphor- } \\
\text { pantetheinyl } \\
\text { transferase }\end{array}$ & $\begin{array}{l}26 \mathrm{kDa} \text {; protein posttranslational modification (PTM) enzyme; } \\
\text { monomer, two domains, pseudo } 2 \text {-fold symmetry }\end{array}$ & pIII & M13 phage & Substrate specificity $^{97}$ \\
\hline \multirow[t]{7}{*}{ Hydrolase } & $\begin{array}{l}\text { Lipase B from Candida } \\
\text { antarctica }\end{array}$ & $\begin{array}{l}33 \mathrm{kDa} \text {; catalytic triad of Ser-His-Asp; no hydrophobic lid = no } \\
\text { interfacial activation; } \alpha / \beta \text { hydrolytic fold }\end{array}$ & $\begin{array}{l}\text { Cwp } \\
\text { Flolp }\end{array}$ & $\begin{array}{l}\text { H. polymorpha } \\
\text { P. pastoris }\end{array}$ & $\begin{array}{l}\text { Activity } \\
\text { Thermostability }^{85}\end{array}$ \\
\hline & $\begin{array}{l}\text { Human } \beta \text { - } \\
\text { glucuronidase }\end{array}$ & $312 \mathrm{kDa}$; glycoprotein, TIM barrel; homotetramer & B7-1 & $\begin{array}{l}\text { Mouse } \\
\text { fibroblasts }\end{array}$ & Activity $^{93}$ \\
\hline & ApeE esterase & $67 \mathrm{kDa}$; GDSL family outer membrane serine esterase/lipase & AIDA-I & E. coli & Activity $^{150}$ \\
\hline & $\begin{array}{l}\text { Rhizomucor miehei } \\
\text { lipase }\end{array}$ & $\begin{array}{l}31.6 \mathrm{kDa} \text {; single polypeptide chain, singly wound } \beta \text { sheet domain; } \\
\text { catalytic triad Ser-His-Asp, amphipathic helix lid }\end{array}$ & Flolp & P. pastoris & Stability ${ }^{89,90}$ \\
\hline & Cel5A hydrolase & $\begin{array}{l}38 \mathrm{kDa} \text {; single catalytic domain, compact } 8 \text {-fold } \beta / \alpha \text {-barrel; Cys- } \\
\text { Cys disulfide bridge }\end{array}$ & INP & E. coli & Thermostability $^{84}$ \\
\hline & $\begin{array}{l}\text { Tobacco Etch Virus } \\
\text { protease }\end{array}$ & $\begin{array}{l}27 \mathrm{kDa} \text {; Cys endopeptidase; cleavage product of single massive } \\
\text { polyprotein, two domain antiparallel } \beta \text {-barrel fold }\end{array}$ & Aga2 & S. cerevisiae & $\begin{array}{l}\text { Substrate } \\
\text { specificity }^{100}\end{array}$ \\
\hline & Bacillus subtilis lipase A & $\begin{array}{l}19 \mathrm{kDa} \text {; catalytic triad Ser-His-Asp; no interfacial activation; } \\
\text { compact minimal } \alpha / \beta \text { hydrolytic fold }\end{array}$ & pIII & M13 phage & Enantioselectivity ${ }^{112}$ \\
\hline Lyase & $\begin{array}{l}\text { Bacillus subtilis } \\
\text { endoxylanase XynA }\end{array}$ & $21.2 \mathrm{kDa}$; glycosyl hydrolase; $\beta$-jelly roll fold & pIII & M13 phage & Thermostability $^{83}$ \\
\hline Ligase & $\begin{array}{l}\text { Non-ribosomal } \\
\text { peptide synthetase }\end{array}$ & Large multimodular enzyme & Aga2 & S. cerevisiae & Substrate specificity $^{92}$ \\
\hline
\end{tabular}

$50 \%$ residual activity for a relatively short time duration (a few hours to $4-5$ days $).{ }^{83-86}$

Lipases are one class of enzymes that have demonstrated the potential to generate biofuels by the esterification of free fatty acids. However, many lipases can be inactivated not only at high temperatures but also in the presence of organic solvents such as methanol, both of which are required for efficient biodiesel production. ${ }^{87}$ For this reason, considerable research has been focused on improving the methanol tolerance of biodieselproducing lipases, in addition to thermostability. ${ }^{85,88,89}$ However, the aqueous conditions of high-throughput screening systems designed to identify hydrolytic enzyme activity is not suitable for selecting lipases, of which the catalytic activity requires a non-aqueous environment. To address this issue, Zhang et al. ${ }^{90}$ developed a new screening technique to identify thermostable mutants of Rhizomucor miehei lipase (RML). Saturation mutagenesis was used to generate the mutant libraries, and the resulting RML variants were displayed on the surface of yeast cells. Unlike the conventional surface screening techniques applied in most studies described in Table 2, screening for thermostable RML mutants was performed at $70{ }^{\circ} \mathrm{C}$ by combining yeast surface display with $\mathrm{pH}$ monitoring and colony plating using organic media into a comprehensive highthroughput screening system. ${ }^{90}$ Thermostable enzymes were identified by heating the plates with yeast colonies grown on BMMG (buffered minimal methanol media)/BMMY (buffered methanol complex media) prior to the addition of the reaction substrate. Active and thermostable mutants then utilized the substrate, tributyrin, to form a halo around the corresponding yeast colony. This technique enabled the visual identification of improved lipases via non-aqueous screening, allowing for the rapid selection of thermostable mutants.

3.1.2. Enzyme Activity and Substrate Specificity. Being crucial parameters for the overall economy of a process, extensive efforts have been made to improve the activity and substrate specificity of enzymes using cell surface display ${ }^{6,75,91-97}$ (Table
2). However, the majority of such studies have relied on conventional low-throughput assays for mutant identification, similar to those used for soluble proteins, indicating the employment of cell surface display to bypass protein purification rather than a high-throughput screening tool. For protein affinity engineering, cell surface display has been routinely used in combination with FACS, which allows the screening of a few thousand cells per second. ${ }^{98}$ To harness its power in highthroughput screening of improved enzymes, the main challenge lies in establishing a stable link between the activity or substrate specificity of a mutant enzyme with the clone that harbors that particular mutant, i.e., preventing dissociation of the reaction product from the cell that expresses that enzyme. Thus, there is a need for a more elegant design that can help to overcome this particular drawback, and two recent studies on protease engineering using cell surface display have done just that. Several industries, including sanitation, food, pharmaceuticals, biomed$\mathrm{ical}$, and waste management, have seen a growing interest in employing protease-based biocatalysts in their processes. ${ }^{99}$ Although similar in their approaches, which involved FACS detection of the products generated from selective proteolysis of a multidomain protein substrate, the two studies differed in the location where the proteolytic cleavage took place.

In the first system, ${ }^{100}$ named yeast endoplasmic reticulum sequestration screening (YESS), proteolysis occurred intracellularly in the endoplasmic reticulum (ER) due to the addition of an ER retention signal peptide that directed both the enzyme variant and multiepitope tagged substrate to the ER. Protease mutants with altered substrate specificities cleaved at different residues, generating products with unique epitope tag combinations, but each proteolytic event resulted in the removal of the ER retention sequence. As a result, each uniquely tagged product was displayed on the yeast surface as an Aga2 fusion protein. Surface staining using epitope-specific antibodies coupled with FACS analysis enabled the detection of unique fluorescent profiles, which indicated selective cleavage by the protease variant. 
Additionally, improved activity of the enzyme mutant was identified based on the intensity of the fluorescence.

In the second study, ${ }^{101}$ enzymatic cleavage took place extracellularly by co-displaying the enzyme variant and the substrate on the cell surface. The authors showed that a protease variant with altered substrate specificity would cleave at amino acid residues other than a basic residue, such as hydrophobic, aromatic, polar, or negatively charged residues. This differential cleavage specificity was linked to the release or retention of an autoinhibitory peptide on the substrate. Removal of the inhibitor peptide by an altered protease would enable binding of a fluorescent dye, whereas its retention would not allow fluorescence labeling. The difference in fluorescence profiles could then be detected by high-throughput screening using FACS. Besides detection of altered specificity profiles, the designs used in these two systems also demonstrated the additional advantage of quantitative evaluation of enzyme activity based on the intensity of the fluorescence profiles.

Recent years have seen an increased interest in developing highly sensitive screening techniques based on microfluidics. ${ }^{102,103}$ By combining in vitro compartmentalization, microfluidics, and cell surface display, Agresti et al. ${ }^{104}$ demonstrated a new screening system that takes advantage of physical separation at the single-cell level, an advantage that is otherwise lost by evaluating a mixed population of cells displaying different variants of the enzyme on the surface. Specifically, yeast cells were engineered to display libraries of horseradish peroxidase (HRP) mutants as Aga-2 fusion proteins. The two libraries were generated by error-prone PCR (epPCR) followed by saturation mutagenesis and staggered expression process, respectively. In this system, a distinctive shift from conventional selection process was the compartmentalization of the recombinant yeast cells in picoliter droplets, with each droplet containing at most one yeast cell displaying one particular enzyme mutant. Using a microfluidics device, each picoliter droplet was sorted based on the presence or absence of a fluorescent signal. Droplets with desired enzyme mutants appeared as fluorescent bubbles, whereas those with no yeast cells or inactive enzymes did not emit light. With a sorting rate of 1000 events/s, this ultra-highthroughput system was capable of screening a library size of $\sim 10^{8}$ in about $10 \mathrm{~h},{ }^{104}$ thus offering an efficiency comparable to that of current high-throughput screening techniques, such as FACS and microtiter plate screening.

3.1.3. Enzyme Enantioselectivity. Establishing a stable genotype-phenotype link is vital to the success of any directed evolution process. ${ }^{105}$ Historically, this has proven to be a significant challenge in developing effective screening methods for selection of enantioselective mutants, as the property of enantioselectivity is a kinetic one. Thus, linking high enantioselectivity of a beneficial mutant to the cell expressing that mutant is difficult. ${ }^{106}$ A number of studies have been devoted to the development of high-throughput screening systems with the ability to elucidate the relationship between enzyme mutations and the resulting product selectivity ${ }^{107-112}$ (Table 2 ). One of the more promising studies regarding enantioselectivity engineering was performed by developing a novel, highthroughput screening system called enzyme screening by covalent attachment of products via enzyme display (ESCAPED). ${ }^{113}$ Traditional screening systems allow for the immediate detachment of the enantiomer product following the enzymatic reaction. ESCAPED differs by maintaining a covalent attachment of the reaction product with the enzyme on the host cell surface following the reaction and is therefore amenable to flow cytometric analysis. This system was validated by displaying an error-prone PCR mutant library of the Pseudomonas aeruginosa esterase (EstA) on the surface of E. coli. ${ }^{114}$ The highly selective mutant enzyme presented on the cell surface catalyzed a peroxide radical mediated reaction for the hydrolysis of a tyramide ester substrate ( $S$ - or $R-2-\mathrm{MDA})$. The reaction product was immediately covalently attached to the surface of the bacterial cell due to radical transfer from the tyramide group to a tyrosine residue of an endogenous surface protein. ${ }^{11}$ The surface-displayed enzyme-product complexes were stained with enantiospecific antibodies and screened using FACS to identify mutants exhibiting a high degree of enantioselectivity. This elegant study provided a turning point in simplifying surface engineering of enantioselectivity of biocatalysts.

3.2. Direct Cell Surface Display of Multiple Enzymes. In addition to serving as a powerful screening platform for enzyme engineering, direct surface display of single enzymes has shown some biocatalytic potential. For example, whole-cell biocatalysts displaying single enzymes have been used to degrade toxic pollutants $^{116}$ and exhibited greater activity in biodiesel production than enzymes immobilized on resin beads. ${ }^{117}$ However, these systems are largely restricted to simple, onestep reactions. In contrast, direct surface display of multiple enzymes has been used to engineer novel biocatalysts capable of acting on multiple substrates. One area where direct cell surface display of multiple enzymes has demonstrated success is in the detection or degradation of some pollutants (a process known as bioremediation). One common target of bioremediation is highly toxic organophosphorus pesticides (OPs). OPs have been widely employed in the agricultural industry for decades, and the development of biocatalysts that degrade toxic OPs is an active area of research. ${ }^{11,75,118} \mathrm{~A}$ number of successful whole-cell biocatalysts using direct display of OP-degrading enzymes have been developed, ${ }^{95,119,120}$ including a system utilizing co-display of two enzymes for simultaneous OP detection and degradation. ${ }^{118}$ In this system, organophosphorus hydrolase $(\mathrm{OPH})$ and a methyl parathion hydrolase (MPH)-GFP fusion were codisplayed using truncated INP and Lpp-OmpA anchors, respectively. Because GFP fluorescence intensity is sensitive to environmental $\mathrm{pH}$ and the degradation of OPs by $\mathrm{OPH}$ and $\mathrm{MPH}$ generates protons, the surface-engineered E. coli strain was able to detect and degrade a broad range of OPs by monitoring changes in GFP fluorescence. ${ }^{118}$

Whole-cell biocatalysts utilizing surface-displayed enzymes are also being explored for the production of biofuels. For example, direct co-display of multiple cellulases has shown potential in the degradation of crystalline cellulose, a major bottleneck in the conversion of biomass to biofuels. ${ }^{121}$ One of the most recent breakthroughs in utilizing direct co-display of cellulases for the degradation of crystalline cellulose has been the incorporation of small, non-enzymatic proteins called expansins. ${ }^{122}$ As their name suggests, expansins are believed to act on crystalline cellulose by disrupting hydrogen bonding between cellulose microfibrils, disrupting the structure and increasing the surface area accessible to cellulase enzymes. ${ }^{123}$ In a recent study, Nakatani et al. ${ }^{124}$ coexpressed three cellulases on the $S$. cerevisiae cell surface in addition to a fungal expansin-like protein as $\operatorname{Ag} \alpha 1$-fusions. The resulting strain was able to increase ethanol production from phosphoric acid swollen cellulose (PASC) from 2.3 to $3.4 \mathrm{~g} / \mathrm{L}$. This is one of the first examples of using direct surface display of both enzymatic and non-enzymatic proteins to harness enzyme synergy. 
Whole-cell biocatalysts utilizing direct surface display have received increasing attention as potential food-grade biocatalysts. Innocuous whole-cell biocatalysts not only represent an environmentally friendly alternative to traditional catalytic processes but also have the potential to act on foodstuffs without the use of harmful materials in the production process. For example, the most common method for chemical synthesis of vanillin requires the toxic precursors phenol and guaiacol. ${ }^{125} \mathrm{E}$. coli whole-cell biocatalysts expressing intracellular enzymes have been engineered to produce vanillin using innocuous precursors glucose ${ }^{125}$ and ferulic acid. ${ }^{126}$ Another advantage associated with food-grade biocatalysts is the relatively low energy requirement for activation. Direct display of lipases on P. pastoris has resulted in the generation of safe, whole-cell biocatalysts capable of efficiently enriching the fatty acids EPA and DHA in fish oil with high selectivity, reducing the energy costs associated with downstream separation. ${ }^{129}$ P. pastoris displaying lipases have also been used to produce the fruit-flavored esters, isoamyl acetate and cis-3-hexenyl, exceeding 95\% conversion. ${ }^{128,129}$

3.3. Scaffold-Complexed Multienzyme Surface Display. The most recent development in cell surface display has been the engineering of highly specific, modular protein scaffolds. Owing to the ability of scaffold-complexed systems to surface display multiple heterologous enzymes in highly organized patterns, they can be used to catalyze multistep reactions with a higher catalytic efficiency than the direct codisplay of multiple enzymes due to enzyme-proximity synergy. ${ }^{130,131}$ In nature, protein scaffolds are found in some anaerobic bacteria and are made up of binding modules called cohesins. ${ }^{132}$ These cohesin-containing scaffolds, termed scaffoldins, are loaded with hydrolytic enzymes, each of which has a dockerin domain. The dockerin binds to cohesin in a speciesdependent manner to form a cellulosome complex. Novel designer cellulosomes can be engineered by recombining cohesins from different species into a single construct. Dockerins from species corresponding to the desired cohesins can then be fused to target enzymes to create sophisticated enzyme networks in the extracellular space.

Yeast surface display of designer cellulosomes has been demonstrated as a promising platform for ethanol production from lignocellulosic biomass. Because yeast have the innate machinery to produce high levels of ethanol, yeast with surface displayed scaffoldin-complexed cellulases have the potential to directly ferment sugars freed from cellulose to ethanol. ${ }^{133-135}$ This feature is critical to the development of consolidated bioprocessing (CBP), ${ }^{136,137}$ a highly integrated process configuration with great potential to reduce the cost of lignocellulosic biofuel production. Therefore, yeast surface display of designer cellulosomes for biomass saccharification is an active research area, and several groups have investigated different methods of organizing enzymes in the extracellular space to harness synergistic effects. We have developed one such system using an Aga2-fused trifunctional scaffoldin complexed with three cellulases: endoglucanase, cellobiohydrolase, and $\beta$-glucosidase. The resulting yeast strain showed a 1.6-fold increase in PASC hydrolysis as a result of enzyme-proximity synergy and an additional 5.5-fold increase as a result of enzyme-enzyme synergy. ${ }^{135}$ This idea has been expanded to include self-surface assembly of a two-member miniscaffoldin on the S. cerevisiae cell surface, where one miniscaffoldin contained an Aga2 fusion and the other contained a dockerin fusion. ${ }^{138}$ This elegant design enabled the yeast surface display of multiple minicellulosomes with the same three enzymatic activities on a secondary scaffold to achieve hydrolysis of crystalline cellulose. The engineered yeast biocatalyst was able to achieve an ethanol yield of $1.412 \mathrm{~g} /$ $\mathrm{L}$. The complexity of yeast-displayed scaffolds has been expanded further to include multivalent scaffold structures containing scaffold chains branching off from a surface-displayed Aga2-fused scaffold $^{139}$ and even ill-defined amyloid-like oligomeric cohesin scaffolds. ${ }^{140}$

Another recent study demonstrating improved efficiency of scaffoldin-complexed biocatalysts was performed by Liang et al., ${ }^{141}$ in which a pentavalent scaffold was displayed on the surface of $S$. cerevisiae. The Aga2-fused cohesin scaffold was complexed with an endoglucanase, a cellobiohydrolase, a $\beta$-glucosidase, a cellulose dehydrogenase $(\mathrm{CDH})$, and a lytic polysaccharide monooxygenase (LPMO). The LPMO is believed to cleave cellulose in the presence of $\mathrm{CDH}$, increasing the number of active sites available upon which the other scaffoldin-complexed cellulases can act. The addition of the $\mathrm{CDH}$ and LPMO enzymes increased the ethanol titers from PASC from 1.8 to $2.7 \mathrm{~g} / \mathrm{L}$.

Yeast surface display is not the only system used for scaffoldincomplexed surface display. Bacterial systems utilizing Bacillus subtilis and E. coli have also demonstrated potential to surface display designer cellulosomes. ${ }^{142}$ In the context of biofuel production and CBP, the optimal host for scaffoldin-complexed surface display of enzymes depends on a number of factors including metabolite tolerance, the innate fermentation machinery, process stability, and the amenability to scale-up. Due to the well-established genetic toolbox and its long history of industrial ethanol production, $S$. cerevisiae is among the most popular host systems being explored for the production of fuels from cellulosic biomass. ${ }^{51,143}$

3.4. Biocatalytic Process Considerations for SurfaceDisplayed Enzymes. Despite success on the laboratory scale, there are several considerations that arise for the industrial use of multicomponent whole-cell biocatalysts (direct co-display and scaffoldin-complexed cell surface display). Like intracellular expression systems, surface-display-based biocatalysts are derived from living organisms and therefore require special processing steps to maintain activity (removal of dead cells, selectable markers to remove wild-type contaminating strains, etc.). Furthermore, complex multicomponent biocatalysts using cell surface display often require the expression of multiple proteins and therefore special attention should be given to balancing protein expression. Additionally, as the number of enzymes expressed in a single whole-cell biocatalysts increases, plasmid stability can become a serious issue when attempting to scale-up biocatalytic processes from the laboratory scale. ${ }^{144}$ Enzyme expression can be controlled in part by careful selection of the type and strength of the promoters that initiate protein expression. Cells harboring biocatalytic proteins under an inducible promoter will not express that protein until they are given a specific substrate to unlock the target gene for transcription. Surface-displayed proteins regulated by an inducible promoter often express the target protein at high concentrations; however, in many applications, the high levels of foreign protein expression are toxic to cells. ${ }^{145}$ Therefore, biocatalysts utilizing high-density surface display of target enzymes under inducible promoters are more suited for batch processing. On the contrary, cells harboring enzymes under a constitutive promoter will express the enzyme continuously, albeit at a lower level than enzymes under inducible promoters. This is advantageous in that it does not require the use of expensive inducing agents or separate growth and induction media that can be problematic on a large scale. As a result, 
constitutive expression is more suited for continuous processes. ${ }^{146}$ However, it should be noted that there is a lack of strong constitutive promoters in many prokaryotic hosts. ${ }^{145}$ Some studies have suggested that the combined use of inducible and constitutive promoters enhances the overall expression of the target enzyme. ${ }^{147,148}$

\section{CONCLUSIONS AND OUTLOOK}

While engineering the properties of biocatalysts using cell surface display and directed evolution has greatly expanded their industrial applicability, the majority of these studies have focused on altering one enzyme property at a time. This approach does not take into consideration the consequences of sequence mutations on other enzyme properties. Therefore, future engineering effort should include strategies for multiparameter screening to evaluate several properties of an enzyme simultaneously. Smart design of enzyme libraries is likely to be the key to the success of this effort, underscoring the importance of predictive modeling and rational design in engineering an optimal biocatalyst for a set of conditions. Real-time evaluation of the effect of mutations on multiple enzyme properties could prove to be a more holistic approach to identifying enzyme species optimized for the chemical industry. Cell surface display combined with multiplexed single-cell screening technologies like FACS offers a clear advantage over other library screening techniques in that it offers the potential for multiparameter screening. The development of such a well-designed system is exemplified by the YESS system, ${ }^{100}$ where the protease was screened for both improved activity and altered selectivity.

Additionally, most biocatalyst engineering strategies have been focused on the local optimization of individual enzymes in isolation. To date, there has been little research focused on the engineering of individual enzymes in the context of a multienzyme system toward a global optimum. Cell surface display, especially co-display and scaffoldin-complexed display systems, represents a great platform to integrate protein engineering with microbial surface engineering for the development of superior industrial whole-cell biocatalysts. As the application of scaffoldin-complexed enzyme biocatalysts continues to advance, collective enzyme engineering strategies will likely be developed to enhance the overall performance of the multienzyme system. This research venue will require rapid, high-dimensional analysis of many enzyme properties, with each property corresponding to different enzymes used for a particular industrial application.

Biocatalytic processes represent a safe, environmentally friendly alternative to traditional catalytic processes. While chemicals produced in biocatalytic processes currently account for $6.2 \%$ of all chemical sales, they are expected to grow to $19.2 \%$ of all chemical sales by $2020 .^{13}$ The transition toward intracellular whole-cell biocatalysis has been ongoing for the past decade, and several large chemical companies including DSM, Lonza, and BASF are developing processes utilizing whole-cell biocatalysts for the production of insecticides, antibiotics, and drug precursors. ${ }^{1}$ While no large-scale production processes utilizing cell surface display are used in industry today, this increasing prevalence of biocatalytic systems in industry coupled with advances in cell surface display will likely accelerate the adoption of whole-cell biocatalysts displaying enzymes.

\section{AUTHOR INFORMATION}

\section{Corresponding Author}

*Tel.: 734-764-8723. E-mail: feiwenum@umich.edu.

\section{Notes}

The authors declare no competing financial interest.

\section{ACKNOWLEDGMENTS}

The authors would like to acknowledge the financial support provided by the Department of Chemical Engineering and MCubed at the University of Michigan and NIH/NCI grant CA191952. We would also like to thank members of the Wen research group for insightful feedback and comments on this review.

\section{REFERENCES}

(1) Schmid, A.; Dordick, J. S.; Hauer, B.; Kiener, A.; Wubbolts, M.; Witholt, B. Industrial biocatalysis today and tomorrow. Nature 2001, 409, 258-268.

(2) Rothenberg, G. Kirk-Othmer Encyclopedia of Chemical Technology; John Wiley \& Sons, Inc.: Hoboken, NJ, 2000.

(3) Johannes, T. W.; Simurdiak, M. R.; Zhao, H. Biocatalysis. In Encyclopedia of Chemical Processing; Lee, S., Ed.; Taylor \& Francis: New York, 2006; pp 101-110.

(4) Schoemaker, H. E.; Mink, D.; Wubbolts, M. G. Dispelling the myths-biocatalysis in industrial synthesis. Science 2003, 299, 16941697.

(5) Faber, K. Biotransformations in Organic Chemistry; Springer-Verlag: Berlin, 2011; pp 9-10.

(6) Bommarius, A.; Riebel, B. Introduction to biocatalysis. Biocatalysis: Fundamentals and Applications; Wiley-VCH: Weinheim, Germany, 2004; pp 1-18.

(7) Frock, A. D.; Kelly, R. M. Extreme thermophiles: moving beyond single-enzyme biocatalysis. Curr. Opin. Chem. Eng. 2012, 1, 363-372.

(8) Jemli, S.; Ayadi-Zouari, D.; Hlima, H. B.; Bejar, S. Biocatalysts: application and engineering for industrial purposes. Crit. Rev. Biotechnol. 2014, 8551, 1-13.

(9) Applied Biocatalysis, 2nd ed.; Straathof, A. J., Adlercreutz, P., Eds.; CRC Press: Boca Raton, FL, 2000.

(10) Ni, Y.; Chen, R. R. Accelerating whole-cell biocatalysis by reducing outer membrane permeability barrier. Biotechnol. Bioeng. 2004, 87, 804-811.

(11) Yang, J.; Liu, R.; Jiang, H.; Yang, Y.; Qiao, C. Selection of a wholecell biocatalyst for methyl parathion biodegradation. Appl. Microbiol. Biotechnol. 2012, 95, 1625-1632.

(12) Ishige, T.; Honda, K.; Shimizu, S. Whole organism biocatalysis. Curr. Opin. Chem. Biol. 2005, 9, 174-180.

(13) Schüürmann, J.; Quehl, P.; Festel, G.; Jose, J. Bacterial whole-cell biocatalysts by surface display of enzymes: toward industrial application. Appl. Microbiol. Biotechnol. 2014, 98, 8031-8046.

(14) Reetz, M. T. Biocatalysis in organic chemistry and biotechnology: past, present, and future. J. Am. Chem. Soc. 2013, 135, 12480-12496.

(15) Bornscheuer, U. T.; Huisman, G. W.; Kazlauskas, R. J.; Lutz, S.; Moore, J. C.; Robins, K. Engineering the third wave of biocatalysis. Nature 2012, 485, 185-194.

(16) Arnold, F. Design by directed evolution. Acc. Chem. Res. 1998, 31, 125-131.

(17) Smith, G. P. Filamentous fusion phage: novel expression vectors that display cloned antigens on the virion surface. Science 1985, 228, 1315-1317.

(18) Makela, A.; Oker-Blom, C. The baculovirus display technologyan evolving instrument for molecular screening and drug delivery. Comb. Chem. High Throughput Screening 2008, 11, 86-98.

(19) Xu, X.; Gao, C.; Zhang, X.; Che, B.; Ma, C.; Qiu, J.; Tao, F.; Xu, P. Production of $N$-acetyl-D-neuraminic acid by use of an efficient spore surface display system. Appl. Environ. Microbiol. 2011, 77, 3197-3201. 
(20) Freudl, R.; MacIntyre, S.; Degen, M.; Henning, U. Cell surface exposure of the outer membrane protein OmpA of Escherichia coli K-12. J. Mol. Biol. 1986, 491-494.

(21) Boder, E.; Wittrup, K. Yeast surface display for screening combinatorial polypeptide libraries. Nat. Biotechnol. 1997, 15.

(22) Wu, Y.; Cain-Hom, C.; Choy, L.; Hagenbeek, T. J.; de Leon, G. P.; Chen, Y.; Finkle, D.; Venook, R.; Wu, X.; Ridgway, J.; Schahin-Reed, D.; Dow, G. J.; Shelton, A.; Stawicki, S.; Watts, R. J.; Zhang, J.; Choy, R.; Howard, P.; Kadyk, L.; Yan, M.; Zha, J.; Callahan, C. A.; Hymowitz, S. G.; Siebel, C. W. Therapeutic antibody targeting of individual Notch receptors. Nature 2010, 464, 1052-1057.

(23) Shi, L.; Wheeler, J. C.; Sweet, R. W.; Lu, J.; Luo, J.; Tornetta, M.; Whitaker, B.; Reddy, R.; Brittingham, R.; Borozdina, L.; Chen, Q; Amegadzie, B.; Knight, D. M.; Almagro, J. C.; Tsui, P. De novo selection of high-affinity antibodies from synthetic fab libraries displayed on phage as pIX fusion proteins. J. Mol. Biol. 2010, 397, 385-396.

(24) Pershad, K.; Pavlovic, J. D.; Gräslund, S.; Nilsson, P.; Colwill, K.; Karatt-Vellatt, A.; Schofield, D. J.; Dyson, M. R.; Pawson, T.; Kay, B. K.; McCafferty, J. Generating a panel of highly specific antibodies to 20 human SH2 domains by phage display. Protein Eng., Des. Sel. 2010, 23, 279-288.

(25) Chen, K.; Sun, X.; Niu, G.; Ma, Y.; Yap, L.-P.; Hui, X.; Wu, K.; Fan, D.; Conti, P. S.; Chen, X. Evaluation of ${ }^{64} \mathrm{Cu}$ labeled GX1: a phage display peptide probe for PET imaging of tumor vasculature. Mol. Imaging Biol. 2012, 14, 96-105.

(26) Deutscher, S. L. Phage display in molecular imaging and diagnosis of cancer. Chem. Rev. 2010, 110, 3196-3211.

(27) Khurana, S.; Chearwae, W.; Castellino, F.; Manischewitz, J.; King, L. R.; Honorkiewicz, A.; Rock, M. T.; Edwards, K. M.; Del Giudice, G.; Rappuoli, R.; Golding, H. Vaccines with MF59 adjuvant expand the antibody repertoire to target protective sites of pandemic avian $\mathrm{H} 5 \mathrm{~N} 1$ influenza virus. Sci. Transl. Med. 2010, 2, 15 ra5.

(28) Khurana, S.; Verma, N.; Yewdell, J. W.; Hilbert, A. K.; Castellino, F.; Lattanzi, M.; Del Giudice, G.; Rappuoli, R.; Golding, H. MF59 adjuvant enhances diversity and affinity of antibody-mediated immune response to pandemic influenza vaccines. Sci. Transl. Med. 2011, 3, $85 \mathrm{ra} 48$.

(29) Szabó, A.; Héja, D.; Szakács, D.; Zboray, K.; Kékesi, K. a; Radisky, E. S.; Sahin-Tóth, M.; Pál, G. High affinity small protein inhibitors of human chymotrypsin C (CTRC) selected by phage display reveal unusual preference for $\mathrm{P}^{\prime}$ acidic residues. J. Biol. Chem. 2011, 286, 22535-22545.

(30) Héja, D.; Harmat, V.; Fodor, K.; Wilmanns, M.; Dobó, J.; Kékesi, K. A.; Závodszky, P.; Gál, P.; Pál, G. Monospecific inhibitors show that both mannan-binding lectin-associated serine protease-1 (MASP-1) and -2 are essential for lectin pathway activation and reveal structural plasticity of MASP-2. J. Biol. Chem. 2012, 287, 20290-20300.

(31) Piotukh, K.; Geltinger, B.; Heinrich, N.; Gerth, F.; Beyermann, M.; Freund, C.; Schwarzer, D. Directed evolution of sortase A mutants with altered substrate selectivity profiles. J. Am. Chem. Soc. 2011, 133, 17536-17539.

(32) Gasparian, M. E.; Bobik, T. V.; Kim, Y. V.; Ponomarenko, N. A.; Dolgikh, D. A.; Gabibov, A. G.; Kirpichnikov, M. P. Heterogeneous catalysis on the phage surface: display of active human enteropeptidase. Biochimie 2013, 95, 2076-2081.

(33) Fernandez-Gacio, A.; Uguen, M.; Fastrez, J. Phage display as a tool for the directed evolution of enzymes. Trends Biotechnol. 2003, 21, 408414.

(34) Levin, A. M.; Weiss, G. A. Optimizing the affinity and specificity of proteins with molecular display. Mol. BioSyst. 2006, 2, 49-57.

(35) Lee, S. Y.; Choi, J. H.; Xu, Z. Microbial cell-surface display. Trends Biotechnol. 2003, 21, 45-52.

(36) Knez, K.; Noppe, W.; Geukens, N.; Janssen, K. P. F.; Spasic, D.; Heyligen, J.; Vriens, K.; Thevissen, K.; Cammue, B. P. a; Petrenko, V.; Ulens, C.; Deckmyn, H.; Lammertyn, J. Affinity comparison of $\mathrm{p} 3$ and p8 peptide displaying bacteriophages using surface plasmon resonance. Anal. Chem. 2013, 85, 10075-10082.
(37) Van Bloois, E.; Winter, R. T.; Kolmar, H.; Fraaije, M. W. Decorating microbes: surface display of proteins on Escherichia coli. Trends Biotechnol. 2011, 29, 79-86.

(38) Schneewind, O.; Missiakas, D. M. Protein secretion and surface display in Gram-positive bacteria. Philos. Trans. R. Soc., B 2012, 367, $1123-1139$.

(39) Francisco, J. Transport and anchoring of beta-lactamase to the external surface of Escherichia coli. Proc. Natl. Acad. Sci. U.S.A. 1992, 89, 2713-2717.

(40) Yang, C.; Zhao, Q.; Liu, Z.; Li, Q.; Qiao, C.; Mulchandani, A.; Chen, W. Cell surface display of functional macromolecule fusions on Escherichia coli for development of an autofluorescent whole-cell biocatalyst. Environ. Sci. Technol. 2008, 42, 6105-6110.

(41) Wei, W.; Liu, X.; Sun, P.; Wang, X.; Zhu, H.; Hong, M.; Mao, Z.W.; Zhao, J. Simple whole-cell biodetection and bioremediation of heavy metals based on an engineered lead-specific operon. Environ. Sci. Technol. 2014, 48, 3363-3371.

(42) Maurer, J.; Jose, J.; Meyer, T. F. Autodisplay: one-component system for efficient surface display and release of soluble recombinant proteins from Escherichia coli. J. Bacteriol. 1997, 179, 794-804.

(43) Jung, H. C.; Lebeault, J. M.; Pan, J. G. Surface display of Zymomonas mobilis levansucrase by using the ice-nucleation protein of Pseudomonas syringae. Nat. Biotechnol. 1998, 16, 576-580.

(44) Jose, J.; Meyer, T. F. The autodisplay story, from discovery to biotechnical and biomedical applications. Microbiol. Mol. Biol. Rev. 2007, $71,600-619$.

(45) Nicolay, T.; Vanderleyden, J.; Spaepen, S. Autotransporter-based cell surface display in Gram-negative bacteria. Crit. Rev. Microbiol. 2013, $7828,1-15$

(46) Jose, J.; von Schwichow, S. Autodisplay of active sorbitol dehydrogenase $(\mathrm{SDH})$ yields a whole cell biocatalyst for the synthesis of rare sugars. ChemBioChem 2004, 5, 491-499.

(47) Detzel, C.; Maas, R.; Tubeleviciute, A.; Jose, J. Autodisplay of nitrilase from Klebsiella pneumoniae and whole-cell degradation of oxynil herbicides and related compounds. Appl. Microbiol. Biotechnol. 2013, 97, 4887-4896.

(48) Jose, J.; Maas, R. M.; Teese, M. G. Autodisplay of enzymesmolecular basis and perspectives. J. Biotechnol. 2012, 161, 92-103.

(49) Karami, A.; Latifi, A. M.; Khodi, S. Comparison of the organophosphorus hydrolase surface display using InaVN and LppOmpA systems in Escherichia coli. J. Microbiol. Biotechnol. 2014, 24, 379-385.

(50) Li, L.; Kang, D. G.; Cha, H. J. Functional display of foreign protein on surface of Escherichia coli using N-terminal domain of ice nucleation protein. Biotechnol. Bioeng. 2004, 85, 214-221.

(51) Fischer, C. R.; Klein-Marcuschamer, D.; Stephanopoulos, G. Selection and optimization of microbial hosts for biofuels production. Metab. Eng. 2008, 10, 295-304.

(52) Ernst, W.; Grabherr, R.; Wegner, D.; Borth, N.; Grassauer, A.; Katinger, H. Baculovirus surface display: Construction and screening of a eukaryotic epitope library. Nucleic Acids Res. 1998, 26, 1718-1723.

(53) Beerli, R. R.; Bauer, M.; Buser, R. B.; Gwerder, M.; Muntwiler, S.; Maurer, P.; Saudan, P.; Bachmann, M. F. Isolation of human monoclonal antibodies by mammalian cell display. Proc. Natl. Acad. Sci. U.S.A. 2008, 105, 14336-14341.

(54) Martínez-Pastor, M. T.; Marchler, G.; Schüller, C.; MarchlerBauer, A.; Ruis, H.; Estruch, F. The Saccharomyces cerevisiae zinc finger proteins Msn2p and Msn4p are required for transcriptional induction through the stress response element (STRE). EMBO J. 1996, 15, 22272235.

(55) Marchler, G.; Schüller, C.; Adam, G.; Ruis, H. A Saccharomyces cerevisiae UAS element controlled by protein kinase A activates transcription in response to a variety of stress conditions. EMBO J. 1993, 12, 1997-2003.

(56) Dhar, R.; Sägesser, R.; Weikert, C.; Wagner, A. Yeast adapts to a changing stressful environment by evolving cross-protection and anticipatory gene regulation. Mol. Biol. Evol. 2013, 30, 573-588. 
(57) Pepper, L.; Cho, Y. A decade of yeast surface display technology: where are we now? Comb. Chem. High Throughput Screening 2008, 11, 127-134.

(58) Tanaka, T.; Yamada, R.; Ogino, C.; Kondo, A. Recent developments in yeast cell surface display toward extended applications in biotechnology. Appl. Microbiol. Biotechnol. 2012, 95, 577-591.

(59) Liu, Y.; Zhang, R.; Lian, Z.; Wang, S.; Wright, A. T. Yeast cell surface display for lipase whole cell catalyst and its applications. J. Mol. Catal. B: Enzym. 2014, 106, 17-25.

(60) Blazic, M.; Kovacevic, G.; Prodanovic, O.; Ostafe, R.; GavrovicJankulovic, M.; Fischer, R.; Prodanovic, R. Yeast surface display for the expression, purification and characterization of wild-type and B11 mutant glucose oxidases. Protein Expression Purif. 2013, 89, 175-180.

(61) Yeasmin, S.; Kim, C. H.; Park, H.J.; Sheikh, M. I.; Lee, J. Y.; Kim, J. W.; Back, K. K.; Kim, S. H. Cell surface display of cellulase activity-free xylanase enzyme on Saccharomyces cerevisiae EBY100. Appl. Biochem. Biotechnol. 2011, 164, 294-304.

(62) Gera, N.; Hussain, M.; Rao, B. M. Protein selection using yeast surface display. Methods 2013, 60, 15-26.

(63) Birnbaum, M. E.; Mendoza, J. L.; Sethi, D. K.; Dong, S.; Glanville, J.; Dobbins, J.; Özkan, E.; Davis, M. M.; Wucherpfennig, K. W.; Garcia, K. C. Deconstructing the peptide-MHC specificity of T cell recognition. Cell 2014, 157, 1073-1087.

(64) Wen, F.; Sethi, D. K.; Wucherpfennig, K. W.; Zhao, H. Cell surface display of functional human MHC class II proteins: yeast display versus insect cell display. Protein Eng., Des. Sel. 2011, 24, 701-709.

(65) Bony, M.; Thines-Sempoux, D.; Barre, P.; Blondin, B. Localization and cell surface anchoring of the Saccharomyces cerevisiae flocculation protein Flo1p. J. Bacteriol. 1997, 179, 4929-4936.

(66) Matsumoto, T.; Fukuda, H.; Ueda, M.; Tanaka, A.; Kondo, A. Construction of yeast strains with high cell surface lipase activity by using novel display systems based on the Flolp flocculation functional domain. Appl. Environ. Microbiol. 2002, 68, 4517-4522.

(67) Jiang, Z.-B.; Song, H.-T.; Gupta, N.; Ma, L.-X.; Wu, Z.-B. Cell surface display of functionally active lipases from Yarrowia lipolytica in Pichia pastoris. Protein Expression Purif. 2007, 56, 35-39.

(68) Han, Z.; Han, S.; Zheng, S.; Lin, Y. Enhancing thermostability of a Rhizomucor miehei lipase by engineering a disulfide bond and displaying on the yeast cell surface. Appl. Microbiol. Biotechnol. 2009, 85, 117-126.

(69) Kondo, A.; Shigechi, H.; Abe, M.; Uyama, K.; Matsumoto, T.; Takahashi, S.; Ueda, M.; Tanaka, A.; Kishimoto, M.; Fukuda, H. Highlevel ethanol production from starch by a flocculent Saccharomyces cerevisiae strain displaying cell-surface glucoamylase. Appl. Microbiol. Biotechnol. 2002, 58, 291-296.

(70) Kondo, A.; Ueda, M. Yeast cell-surface display-applications of molecular display. Appl. Microbiol. Biotechnol. 2004, 64, 28-40.

(71) Vallejo, J. A.; Sánchez-Pérez, A.; Martínez, J. P.; Villa, T. G. Cell aggregations in yeasts and their applications. Appl. Microbiol. Biotechnol. 2013, 97, 2305-2318.

(72) Bauer, F. F.; Govender, P.; Bester, M. C. Yeast flocculation and its biotechnological relevance. Appl. Microbiol. Biotechnol. 2010, 88, 31-39. (73) Mohebali, G.; Ball, A. S. Biocatalytic desulfurization (BDS) of petrodiesel fuels. Microbiology 2008, 154, 2169-2183.

(74) Wang, H.; Lang, Q.; Li, L.; Liang, B.; Tang, X.; Kong, L.; Mascini, M.; Liu, A. Yeast surface displaying glucose oxidase as whole-cell biocatalyst: construction, characterization, and its electrochemical glucose sensing application. Anal. Chem. 2013, 85, 6107-6112.

(75) Tang, X.; Liang, B.; Yi, T.; Manco, G.; Palchetti, I.; Palchetti, I.; Liu, A. Cell surface display of organophosphorus hydrolase for sensitive spectrophotometric detection of p-nitrophenol substituted organophosphates. Enzyme Microb. Technol. 2014, 55, 107-112.

(76) Wang, M.; Si, T.; Zhao, H. Biocatalyst development by directed evolution. Bioresour. Technol. 2012, 115, 117-125.

(77) Martínez, R; Schwaneberg, U. A roadmap to directed enzyme evolution and screening systems for biotechnological applications. Biol. Res. 2013, 46, 395-405.

(78) Wen, F.; Mclachlan, M.; Zhao, H. Directed evolution: novel and improved enzymes. Wiley Encyclopedia of Chemical Biology; Wiley: Hoboken, NJ, 2008.
(79) Kumar, A.; Singh, S. Directed evolution: tailoring biocatalysts for industrial applications. Crit. Rev. Biotechnol. 2013, 33, 365-378.

(80) Turner, N. J. Directed evolution drives the next generation of biocatalysts. Nat. Chem. Biol. 2009, 5, 567-573.

(81) Rubin-Pitel, S. B.; Zhao, H. Recent advances in biocatalysis by directed enzyme evolution. Comb. Chem. High Throughput Screening 2006, 9, 247-257.

(82) Fulda, S.; Gorman, A. M.; Hori, O.; Samali, A. Cellular stress responses: cell survival and cell death. Int. J. Cell Biol. 2010, 2010, 214074.

(83) Beliën, T.; Verjans, P.; Courtin, C. M.; Delcour, J. a. Phage display based identification of novel stabilizing mutations in glycosyl hydrolase family 11 B. subtilis endoxylanase XynA. Biochem. Biophys. Res. Commun. 2008, 368, 74-80.

(84) Liu, W.; Zhang, X.-Z.; Zhang, Z.; Zhang, Y.-H. P. Engineering of Clostridium phytofermentans endoglucanase Cel5A for improved thermostability. Appl. Environ. Microbiol. 2010, 76, 4914-4917.

(85) Peng, X.-Q. Improved thermostability of lipase B from Candida antarctica by directed evolution and display on yeast surface. Appl. Biochem. Biotechnol. 2012, 169, 351-358.

(86) Chen, Y.-P.; Hwang, I.-E.; Lin, C.-J.; Wang, H.-J.; Tseng, C.-P. Enhancing the stability of xylanase from Cellulomonas fimi by cellsurface display on Escherichia coli. J. Appl. Microbiol. 2012, 112, 455463.

(87) Korman, T. P.; Sahachartsiri, B.; Charbonneau, D. M.; Huang, G. L.; Beauregard, M.; Bowie, J. U. Dieselzymes: development of a stable and methanol tolerant lipase for biodiesel production by directed evolution. Biotechnol. Biofuels 2013, 6, 70.

(88) Reetz, M. T.; Soni, P.; Fernández, L.; Gumulya, Y.; Carballeira, J. D. Increasing the stability of an enzyme toward hostile organic solvents by directed evolution based on iterative saturation mutagenesis using the B-FIT method. Chem. Commun. 2010, 46, 8657-8658.

(89) Han, S.; Zhang, J.; Han, Z.; Zheng, S.; Lin, Y. Combination of sitedirected mutagenesis and yeast surface display enhances Rhizomucor miehei lipase esterification activity in organic solvent. Biotechnol. Lett. 2011, 33, 2431-2438.

(90) Zhang, J.; Lin, Y.; Sun, Y.; Ye, Y.; Zheng, S.; Han, S. Highthroughput screening of $\mathrm{B}$ factor saturation mutated Rhizomucor miehei lipase thermostability based on synthetic reaction. Enzyme Microb. Technol. 2012, 50, 325-330.

(91) Tan, L.-T.; Hiraishi, T.; Sudesh, K.; Maeda, M. Directed evolution of poly $[(R)$-3-hydroxybutyrate $]$ depolymerase using cell surface display system: functional importance of asparagine at position 285. Appl. Microbiol. Biotechnol. 2013, 97, 4859-4871.

(92) Zhang, K.; Nelson, K. M.; Bhuripanyo, K.; Grimes, K. D.; Zhao, B.; Aldrich, C. C.; Yin, J. Engineering the substrate specificity of the DhbE adenylation domain by yeast cell surface display. Chem. Biol. 2013, 20, 92-101.

(93) Chen, K.-C.; Wu, C.-H.; Chang, C.-Y.; Lu, W.-C.; Tseng, Q.; Prijovich, Z. M.; Schechinger, W.; Liaw, Y.-C.; Leu, Y.-L.; Roffler, S. R. Directed evolution of a lysosomal enzyme with enhanced activity at neutral $\mathrm{pH}$ by mammalian cell-surface display. Chem. Biol. 2008, 15, $1277-1286$.

(94) Kim, S. Y.; Sohn, J. H.; Pyun, Y. R.; Kim, K. H.; Choi, E. S. In vitro evolution of lipase B from Candida antarctica using surface display in Hansenula polymorpha. J. Microbiol. Biotechnol. 2007, 17, 1308-1315.

(95) Gupta, N.; Farinas, E. T. Directed evolution of CotA laccase for increased substrate specificity using Bacillus subtilis spores. Protein Eng., Des. Sel. 2010, 23, 679-682.

(96) Liang, B.; Lang, Q.; Tang, X.; Liu, A. Simultaneously improving stability and specificity of cell surface displayed glucose dehydrogenase mutants to construct whole-cell biocatalyst for glucose biosensor application. Bioresour. Technol. 2013, 147, 492-498.

(97) Sunbul, M.; Marshall, N. J.; Zou, Y.; Zhang, K.; Yin, J. Catalytic turnover-based phage selection for engineering the substrate specificity of Sfp phosphopantetheinyl transferase. J. Mol. Biol. 2009, 387, 883898.

(98) Bonner, W. A.; Hulett, H. R.; Sweet, R. G.; Herzenberg, L. A. Fluorescence activated cell sorting. Rev. Sci. Instrum. 1972, 43, 404-409. 
(99) Gupta, R.; Beg, Q. K.; Lorenz, P. Bacterial alkaline proteases: molecular approaches and industrial applications. Appl. Microbiol. Biotechnol. 2002, 59, 15-32.

(100) Yi, L.; Gebhard, M. C.; Li, Q.; Taft, J. M.; Georgiou, G.; Iverson, B. L. Engineering of TEV protease variants by yeast ER sequestration screening (YESS) of combinatorial libraries. Proc. Natl. Acad. Sci. U.S.A. 2013, 110, 7229-7234.

(101) Yoo, T. H.; Pogson, M.; Iverson, B. L.; Georgiou, G. Directed evolution of highly selective proteases using a novel FACS based screen that capitalizes on the p53 regulator MDM2. ChemBioChem 2012, 13, 649-653.

(102) Paegel, B. M.; Joyce, G. F. Microfluidic compartmentalized directed evolution. Chem. Biol. 2010, 17, 717-724.

(103) Griffiths, A. D.; Tawfik, D. S. Man-made enzymes-from design to in vitro compartmentalisation. Curr. Opin. Biotechnol. 2000, 11, 338353.

(104) Agresti, J. J.; Antipov, E.; Abate, A. R.; Ahn, K.; Rowat, A. C.; Baret, J.-C.; Marquez, M.; Klibanov, A. M.; Griffiths, A. D.; Weitz, D. A. Ultrahigh-throughput screening in drop-based microfluidics for directed evolution. Proc. Natl. Acad. Sci. U.S.A. 2010, 107, 4004-4009.

(105) Acevedo-Rocha, C. G.; Agudo, R.; Reetz, M. T. Directed evolution of stereoselective enzymes based on genetic selection as opposed to screening systems. J. Biotechnol. 2014, 191, 3-10.

(106) Reetz, M. T. Combinatorial and evolution-based methods in the creation of enantioselective catalysts. Angew. Chem., Int. Ed. 2001, 40, 284-310.

(107) Liebeton, K.; Zonta, A.; Schimossek, K.; Nardini, M.; Lang, D.; Dijkstra, B. W.; Reetz, M. T.; Jaeger, K. E. Directed evolution of an enantioselective lipase. Chem. Biol. 2000, 7, 709-718.

(108) Reetz, M. T.; Becker, M. H.; Klien, H.-W.; Stockigt, D. A method for high-throughput screening of enantioselective catalysts. Angew. Chem., Int. Ed. 1999, 38, 1758-1761.

(109) Reetz, M. T.; Zonta, A.; Schimossek, K.; Liebeton, K.; Jaeger, K.E. Creation of enantioselective biocatalysts for organic chemistry by in vitro evolution. Angew. Chem., Int. Ed. Engl. 1997, 36, 2830-2832.

(110) Lipovsek, D.; Antipov, E.; Armstrong, K. A.; Olsen, M. J.; Klibanov, A. M.; Tidor, B.; Wittrup, K. D. Selection of horseradish peroxidase variants with enhanced enantioselectivity by yeast surface display. Chem. Biol. 2007, 14, 1176-1185.

(111) Antipov, E.; Cho, A. E.; Wittrup, K. D.; Klibanov, A. M. Highly L and $\mathrm{D}$ enantioselective variants of horseradish peroxidase discovered by an ultrahigh-throughput selection method. Proc. Natl. Acad. Sci. U.S.A. 2008, 105, 17694-17699.

(112) Dröge, M. J.; Boersma, Y. L.; van Pouderoyen, G.; Vrenken, T. E.; Rüggeberg, C. J.; Reetz, M. T.; Dijkstra, B. W.; Quax, W. J. Directed evolution of Bacillus subtilis lipase A by use of enantiomeric phosphonate inhibitors: crystal structures and phage display selection. ChemBioChem 2006, 7, 149-157.

(113) Becker, S.; Schmoldt, H.-U.; Adams, T. M.; Wilhelm, S.; Kolmar, $\mathrm{H}$. Ultra-high-throughput screening based on cell-surface display and fluorescence-activated cell sorting for the identification of novel biocatalysts. Curr. Opin. Biotechnol. 2004, 15, 323-329.

(114) Becker, S.; Höbenreich, H.; Vogel, A.; Knorr, J.; Wilhelm, S.; Rosenau, F.; Jaeger, K.-E.; Reetz, M. T.; Kolmar, H. Single-cell highthroughput screening to identify enantioselective hydrolytic enzymes. Angew. Chem., Int. Ed. 2008, 47, 5085-5088.

(115) Becker, S.; Michalczyk, A.; Wilhelm, S.; Jaeger, K.-E.; Kolmar, H. Ultrahigh-throughput screening to identify $E$. coli cells expressing functionally active enzymes on their surface. ChemBioChem 2007, 8, 943-949.

(116) Richins, R. D.; Kaneva, I.; Mulchandani, A.; Chen, W. Biodegradation of organophosphorus pesticides by surface-expressed organophosphorus hydrolase. Nat. Biotechnol. 1997, 15, 984-987.

(117) Kim, S.; Song, J. K.; Kim, H. K. Cell surface display of Staphylococcus haemolyticus L62 lipase in Escherichia coli and its application as a whole cell biocatalyst for biodiesel production. J. Mol. Catal. B: Enzym. 2013, 97, 54-61.

(118) Liu, R.; Yang, C.; Xu, Y.; Xu, P.; Jiang, H.; Qiao, C. Development of a whole-cell biocatalyst/biosensor by display of multiple heterologous proteins on the Escherichia coli cell surface for the detoxification and detection of organophosphates. J. Agric. Food Chem. 2013, 61, 78107816.

(119) Shimazu, M.; Mulchandani, A.; Chen, W. Cell surface display of organophosphorus hydrolase using ice nucleation protein. Biotechnol. Prog. 2001, 17, 76-80.

(120) Takayama, K.; Suye, S.; Kuroda, K.; Ueda, M.; Kitaguchi, T.; Tsuchiyama, K.; Fukuda, T.; Chen, W.; Mulchandani, A. Surface display of organophosphorus hydrolase on Saccharomyces cerevisiae. Biotechnol. Prog. 2006, 22, 939-943.

(121) Matano, Y.; Hasunuma, T.; Kondo, A. Simultaneous improvement of saccharification and ethanol production from crystalline cellulose by alleviation of irreversible adsorption of cellulase with a cell surface-engineered yeast strain. Appl. Microbiol. Biotechnol. 2013, 97, 2231-2237.

(122) Chen, X.; Ishida, N.; Todaka, N.; Nakamura, R.; Maruyama, J.; Takahashi, H.; Kitamoto, K. Promotion of efficient saccharification of crystalline cellulose by Aspergillus fumigatus Swo1. Appl. Environ. Microbiol. 2010, 76, 2556-2561.

(123) Arantes, V.; Saddler, J. N. Access to cellulose limits the efficiency of enzymatic hydrolysis: the role of amorphogenesis. Biotechnol. Biofuels $2010,3,4$.

(124) Nakatani, Y.; Yamada, R.; Ogino, C.; Kondo, A. Synergetic effect of yeast cell-surface expression of cellulase and expansin-like protein on direct ethanol production from cellulose. Microb. Cell Fact. 2013, 12, 66.

(125) Li, K.; Frost, J. W. Synthesis of vanillin from glucose. J. Am. Chem. Soc. 1998, 120, 10545-10546.

(126) Barghini, P.; Di Gioia, D.; Fava, F.; Ruzzi, M. Vanillin production using metabolically engineered Escherichia coli under non-growing conditions. Microb. Cell Fact. 2007, 6, 13.

(127) Pan, X.-X.; Xu, L.; Zhang, Y.; Xiao, X.; Wang, X.-F.; Liu, Y.; Zhang, H.; Yan, Y.-J. Efficient display of active Geotrichum sp. lipase on Pichia pastoris cell wall and its application as a whole-cell biocatalyst to enrich EPA and DHA in fish oil. J. Agric. Food Chem. 2012, 60, 96739679.

(128) Jin, Z.; Liang, S.; Zhang, X.; Han, S.; Ren, C.; Lin, Y.; Zheng, S. Synthesis of fructose laurate esters catalyzed by a CALB-displaying Pichia pastoris whole-cell biocatalyst in a non-aqueous system. Biotechnol. Bioprocess Eng. 2013, 18, 365-374.

(129) Jin, Z.; Ntwali, J.; Han, S.-Y.; Zheng, S.-P.; Lin, Y. Production of flavor esters catalyzed by CALB-displaying Pichia pastoris whole-cells in a batch reactor. J. Biotechnol. 2012, 159, 108-114.

(130) Resch, M. G.; Donohoe, B. S.; Baker, J. O.; Decker, S. R.; Bayer, E. a.; Beckham, G. T.; Himmel, M. E. Fungal cellulases and complexed cellulosomal enzymes exhibit synergistic mechanisms in cellulose deconstruction. Energy Environ. Sci. 2013, 6, 1858.

(131) Hyeon, J. E.; Jeon, S. D.; Han, S. O. Cellulosome-based, Clostridium-derived multi-functional enzyme complexes for advanced biotechnology tool development: advances and applications. Biotechnol. Adv. 2013, 31, 936-944.

(132) Schwarz, W. H. The cellulosome and cellulose degradation by anaerobic bacteria. Appl. Microbiol. Biotechnol. 2001, 56, 634-649.

(133) Tsai, S.-L.; Oh, J.; Singh, S.; Chen, R.; Chen, W. Functional assembly of minicellulosomes on the Saccharomyces cerevisiae cell surface for cellulose hydrolysis and ethanol production. Appl. Environ. Microbiol. 2009, 75, 6087-6093.

(134) Tsai, S.-L.; Goyal, G.; Chen, W. Surface display of a functional minicellulosome by intracellular complementation using a synthetic yeast consortium and its application to cellulose hydrolysis and ethanol production. Appl. Environ. Microbiol. 2010, 76, 7514-7520.

(135) Wen, F.; Sun, J.; Zhao, H. Yeast surface display of trifunctional minicellulosomes for simultaneous saccharification and fermentation of cellulose to ethanol. Appl. Environ. Microbiol. 2010, 76, 1251-1260.

(136) Lynd, L. R; van Zyl, W. H.; McBride, J. E.; Laser, M. Consolidated bioprocessing of cellulosic biomass: an update. Curr. Opin. Biotechnol. 2005, 16, 577-583.

(137) Olson, D. G.; McBride, J. E.; Shaw, A. J.; Lynd, L. R. Recent progress in consolidated bioprocessing. Curr. Opin. Biotechnol. 2012, 23, 396-405. 
(138) Fan, L.; Zhang, Z.; Yu, X. Self-surface assembly of cellulosomes with two miniscaffoldins on Saccharomyces cerevisiae for cellulosic ethanol production. Proc. Natl. Acad. Sci. U.S.A. 2012, 1-6.

(139) Tsai, S.-L.; DaSilva, N. A.; Chen, W. Functional display of complex cellulosomes on the yeast surface via adaptive assembly. ACS Synth. Biol. 2013, 2, 14-21.

(140) Han, Z.; Zhang, B.; Wang, Y. E.; Zuo, Y. Y.; Su, W. W. Selfassembled amyloid-like oligomeric-cohesin scaffoldin for augmented protein display on the Saccharomyces cerevisiae cell surface. Appl. Environ. Microbiol. 2012, 78, 3249-3255.

(141) Liang, Y.; Si, T.; Ang, E. L.; Zhao, H. An engineered pentafunctional minicellulosome for simultaneous saccharification and ethanol fermentation in Saccharomyces cerevisiae. Appl. Environ. Microbiol. 2014, 80, 6677-6684.

(142) You, C.; Zhang, X.-Z.; Sathitsuksanoh, N.; Lynd, L. R.; Zhang, Y.-H. P. Enhanced microbial utilization of recalcitrant cellulose by an ex vivo cellulosome-microbe complex. Appl. Environ. Microbiol. 2012, 78, 1437-1444.

(143) Lin, Y.; Tanaka, S. Ethanol fermentation from biomass resources: current state and prospects. Appl. Microbiol. Biotechnol. 2006, 69, 627-642.

(144) Ensley, B. D. Stability of recombinant plasmids in industrial microorganisms. Crit. Rev. Biotechnol. 1986, 4, 263-277.

(145) Xu, Y.; Tao, F.; Ma, C.; Xu, P. New constitutive vectors: useful genetic engineering tools for biocatalysis. Appl. Environ. Microbiol. 2013, 79, 2836-2840.

(146) Goodrick, J. C.; Xu, M.; Finnegan, R.; Schilling, B. M.; Schiavi, S.; Hoppe, H.; Wan, N. C. High-level expression and stabilization of recombinant human chitinase produced in a continuous constitutive Pichia pastoris expression system. Biotechnol. Bioeng. 2001, 74, 492-497.

(147) He, X.; Liu, N.; Li, W.; Zhang, Z.; Zhang, B.; Ma, Y. Inducible and constitutive expression of a novel thermostable alkaline $\beta$ mannanase from alkaliphilic Bacillus sp. N16-5 in Pichia pastoris and characterization of the recombinant enzyme. Enzyme Microb. Technol. 2008, 43, 13-18.

(148) Wu, J. M.; Lin, J. C.; Chieng, L. L.; Lee, C. K.; Hsu, T. A. Combined use of GAP and AOX1 promoter to enhance the expression of human granulocyte-macrophage colony-stimulating factor in Pichia pastoris. Enzyme Microb. Technol. 2003, 33, 453-459.

(149) Schreuder, M. P.; Brekelmans, S.; van den Ende, H.; Klis, F. M. Targeting of a heterologous protein to the cell wall of Saccharomyces cerevisiae. Yeast 1993, 9, 399-409.

(150) Schultheiss, E.; Weiss, S.; Winterer, E.; Maas, R.; Heinzle, E.; Jose, J. Esterase autodisplay: enzyme engineering and whole-cell activity determination in microplates with $\mathrm{pH}$ sensors. Appl. Environ. Microbiol. 2008, 74, 4782-4791. 